\title{
Agama dan Kebudayaan
}

\author{
Amri Marzali \\ Departemen Antropologi dan Sosiologi, Universitas Malaya \\ amarzali@yahoo.com
}

\begin{abstract}
This article discusses religion as concept that rooted from the English terms "religion” and which includes the form of religious revelation, local religion, and natural religion. This articles aims to provide an introduction for the study of religion using socioanthropology perspective; a perspective which combine sociology, social, and cultural anthropology.
\end{abstract}

Keywords: Religion, Culture, Anthropology

\begin{abstract}
Abstrak
Artikel ini membahas agama yang memiliki pengertian sebagai religion dalam bahasa Inggris, termasuk apa yang disebut agama wahyu, agama natural, dan agama lokal. Artikel ini bertujuan memberikan pengantar singkat dalam mempelajari agama menurut disiplin ilmu sosioantropologi, yaitu gabungan dari disiplin ilmu sosiologi, antropologi sosial, dan antropologi kultural.
\end{abstract}

Kata kunci: Agama, Kebudayaan, Antropologi

\section{Pendahuluan}

Tulisan ini dimaksudkan sebagai pengantar singkat dalam mempelajari agama menurut disiplin ilmu sosioantropologi, yaitu gabungan dari disiplin ilmu sosiologi, antropologi sosial, dan antropologi kultural. Kajian terhadap agama dari sudut ilmu sosioantropologi dikenal menggunakan beberapa pendekatan. Antara lain, Thomas O’Dea yang menggunakan pendekatan fungsional, Betty Scharf yang menggunakan pendekatan sosiologis, dan Brian Morris yang menggunakan pendekatan antropologis Scharf 1995/1970; O’Dea 1969; Morris 1987).

Ada begitu banyak buku pelajaran tentang agama dalam ilmu-ilmu sosial, khususnya yang berbahasa Inggris, dan setiap buku mempunyai cara tersendiri dalam penyusunannya. Beberapa antaranya adalah sebagai berikut. Pertama, jenis buku-buku pengantar, misalnya buku
Anthropological Studies of Religion; an Introductory Text oleh Brian Morris (1987); Introducing Anthropology of Religion oleh Jack David Eller (2007); Sociology of Religion oleh Jochim Wach (1977); Kajian Sosiologi Agama (terjemahan) oleh Betty R. Scharf (1995/1970); dan The Sociology of Religion oleh Thomas O'Dea (1969). Kedua adalah jenis buku-buku kumpulan karangan (readings), misalnya buku Agama: Dalam analisa dan Interpretasi Sosiologis (terjemahan) oleh Roland Robertson, ed. (1988/1980); Reader in Comparative Religion: an Anthropological Approach oleh Lessa \& Vogt (1979) dan Antropologi Agama oleh Tony Rudyansjah (2012). Ketiga adalah jenis buku-buku perbandingan agama, misalnya buku-buku The Religion Experience of Mankind oleh Ninian Smart (1980/1965); The Religions of Man oleh Huston Smith (1958); dan Comparative Religion: an Introduction Through Source Materials oleh Michael Pye (1972). 
Keempat, jenis buku-buku perbandingan teori-teori dan pendekatan-pendekatan dalam kajian agama dari sudut ilmu-ilmu sosial, misalnya buku Aneka Pendekatan Studi Agama (terjemahan) oleh Peter Connolly (2009/2002) dan Seven Theories of Religion (terjemahan) oleh Daniel L. Pals (2011/1995). Kelima, terakhir adalah jenis buku-buku pelajaran tentang agama dengan pendekatan dan padangan yang khas milik pengarang itu sendiri, misalnya buku The Sacred Canopy oleh Peter L. Berger (1969), The Invisible Religion oleh Thomas Luckmann (1972), dan The Sociology of Religion oleh Harold Fallding (1974).

\section{Agama dalam perspektif}

Istilah agama dalam kajian sosioantropologi adalah terjemahan dari kata religion dalam bahasa Inggris, tidak sama dengan istilah agama dalam bahasa politik-administratif pemerintah Republik Indonesia. Dalam karangan ini, agama adalah semua yang disebut religion dalam bahasa Inggris, termasuk apa yang disebut agama wahyu, agama natural, dan agama lokal. “Agama” dalam pengertian politik-administratif pemerintah Republik Indonesia adalah agama resmi yang diakui oleh pemerintah, yaitu Islam, Kristen Protestan, Katolik, Hindu dan Budha, dan pada masa akhir-akhirnya ini juga dimasukan agama Kongkucu (Saifudin 2000: 2). Perbedaan antara istilah agama yang digunakan dalam karangan ini dengan yang digunakan oleh pemerintah Republik Indonesia tidak akan dibahas lebih jauh, karena berlakunya adalah khas di Indonesia saja.

\section{Pendekatan Sosioantropologis dalam Kajian tentang Agama.}

Sosioantropologi berasal dari sinkronisasi disiplin ilmu social anthropology yang menjadi tradisi di Inggris dan cultural anthropology yang menjadi tradisi di USA. Penulis memilih untuk tidak mengikuti salah satu dari kedua tradisi ini, tetapi menggabungkannya secara elektif. Penulis berpendapat bahwa hal ini lebih tepat dan lebih sesuai untuk masyarakat Indonesia yang sedang bergerak meninggalkan tipe masyarakat pertanian, perdesaan dan tradisional menuju pada tipe masyarakat industri, perkotaan dan moderen. Perbedaan dan persamaan dari kedua antropologi ini terutama terletak pada subject matter kajiannya.

Subject matter kajian antropologi sosial adalah sama dengan sosiologi, yaitu hubungan-hubungan sosial yang terkristal dalam struktur sosial dan institusi sosial suatu komunitas. Namun, berbeda dari sosiologi yang memiliki tradisi mempelajari komuniti-komuniti industri, perkotaan dan moderen, maka antropologi sosial mengkaji struktur sosial dan institusi sosial milik komuniti-komuniti kecil arkaik-tradisional di perdesaan, karena itu antropologi sosial juga disebut micro sosiology. Perbedaan kedua terletak pada cara pengambilan kesimpulan umum. Berbeda dari sosiologi yang umumnya mengambil kesimpulan umum dengan cara statistik dan kuantitatif, maka antropologi sosial mengambil kesimpulan dengan cara komparatif dan kualitatif. Oleh karena itu antropologi sosial juga disebut dengan nama comparative sociology. Sosioantropologi mempertahankan pendekatan kualitatif, tetapi perhatian diberikan kepada jenis-jenis komunitas yang lebih luas, baik komunitas arkaik-tradisional maupun komunitas industri-moderen. Dengan demikian aneka fenomena keagamaan yang dibahas termasuk fenomena keagamaan yang berasal dari kedua jenis komunitas tersebut.

Sementara itu subject matter dari kajian antropologi kultural Amerika adalah budaya (culture) dari komunitas. Meski antropologi sosial juga mempelajari budaya, tetapi cara pandang kedua jenis antropologi itu terhadap budaya adalah 
berbeda. Bagi arus utama antropologi kultural USA, sejak tahun 1960an budaya dilihat sebagai sistem ideasional (sistem gagasan) yang berada di belakang polapola perilaku komunitas, yaitu di belakang struktur sosial dan institusi sosial komunitas tersebut. Salah satu definisi dari budaya yang berpengaruh dalam aliran antropologi kultural adalah seperti yang dikatakan Haviland (1990):

"Culture is a set of standards shared by members of a society, which when acted upon by the members, produce behavior that falls within a range of variation the members consider proper and acceptable.”

"A set of standard" atau sistem gagasan ini dapat dalam bentuk "structures of meaning" atau "system of knowledge," atau berbagai bentuk sistem gagasan lain (Geertz 1973; Spradley 1973). Yang penting untuk dipahami adalah bahwa " $a$ set of standard" atau sistem gagasan ini dilihat sebagai penentu utama (determinant) dari pola-pola perilaku komunitas. Bagi antropologi sosial Inggris, budaya bukanlah subjek kajian utamanya. Budaya dilihat hanya sebagai pelengkap atau subordinat (subsidiary; ancillary) terhadap struktur sosial dan institusi sosial (Lewis 2003: ix). Budaya, dalam pandangan antropologi sosial, bisa diumpamakan seperti pakaian yang dipakai oleh sebuah masyarakat, bukan bangunan badan struktur masyarakat itu sendiri. Budaya adalah perwujudan dari adat-adat yang khas yang membedakan satu kelompok masyarakat dari kelompok masyarakat yang lain, dan memberi jatidiri yang khas bagi masyarakat tersebut.

Bagaimanapun setelah tahun 1960an, perbedaan antara Antropologi Sosial Inggris dan Antropologi Kultural Amerika makin menyempit. Dikatakan bahwa apa yang disebut "sosial struktur" oleh tokoh sumber inspirasi Antropologi Sosial Inggris, yaitu Durkheim, adalah persis sama seperti apa yang dimaksud dengan "kultur" oleh Goodenough, seorang pemikir konsep kultur dalam Antropologi Kultural Amerika. Kedua konsep ini mengacu kepada "aturan-aturan” atau "grammar" kehidupan sosial (Durkheim 1966; Goodenough 1981). Banyak yang mengatakan bahwa perbedaan antara Antropologi Sosial (Inggris) dari Antropologi Kultural (Amerika) hanyalah semacam dua label dari satu botol yang sama. Pembahasan tentang perbedaan tradisi antropologi sosial Inggris dan antropologi kultural Amerika tidak akan diperpanjang lebih jauh, karena hal ini hanyalah sekedar sebagai pembanding saja dalam memahami pendekatan keilmuan yang diambil dalam sosioantropologi.

\section{Definisi Agama Sosioantropologi}

Dari sudut pandang sosioantropologi, atau ilmu-ilmu sosial pada umumnya, agama adalah berkaitan dengan kepercayaan (belief) dan upacara (ritual) yang dimiliki bersama oleh suatu kelompok masyarakat. Agama berkaitan dengan 'transcends experience' kata sosiologist Itali, Vilfredo Pareto, yaitu pengalaman dengan 'Yang di atas', atau sesuatu yang berada di luar, sesuatu yang tidak terjamah (an intangible beyond). Agama begitu penting dalam kehidupan manusia, mengandung aspirasiaspirasi manusia yang paling dalam (sublime), sumber dari semua budaya tinggi, bahkan candu bagi manusia kata Karl Marx (O’Dea 1966: 2).

Definisi mengenai agama dalam dunia akademik adalah masalah pelik. Penuh perdebatan yang serius. Cara seorang ahli mendefinisikan agama akan berisi tentang penjelasan orang itu tentang peranan agama dalam masyarakat. Definisi itu juga mencerminkan penafsiran seorang ahli tentang isu-isu yang berkaitan dengan agama, seperti perubahan sosial, modernitas, agama tanpa gereja, dan sebagainya. Oleh karena itu diusulkan agar lebih baik membuat definisi untuk 
kegunaan strategi saja, bukan sebagai pernyataan tentang 'kebenaran.' Satu definisi strategi memberi kemudahan bagi kita untuk memfokuskan bidang perbincangan dan memberi panduan kepada cara berpikir tentang agama. Definisi itu tergantung kepada seberapa berguna definisi tersebut untuk keperluan kajian kita. Karena itu, tidak terlarang kita membuat definisi tentang agama yang berlainan dari yang dibuat oleh orang lain (McGuire 2002: 8).

Jenis definisi strategi yang biasa digunakan oleh ahli sosioantropologi adalah definisi substantif dan definisi fungsional. Definisi substantif berusaha membangun pengertian tentang apa agama itu; manakala definisi fungsional menggambarkan apa yang dibuat oleh agama. Contoh definisi substantif, misalnya adalah dari Melford Spiro, yang mengatakan agama adalah "Satu institusi yang terdiri dari pola-pola interaksi kultural dengan makhluk-makhluk adikodrati yang dipercayai secara kultural" (An institution consisting of culturally patterned interaction with culturally postulated superhuman beings) (Spiro 1966: 96). Yang dimaksudkan dengan 'institusi' disini adalah 'pola-pola perilaku dan kepercayaan yang dimiliki bersama oleh satu masyarakat' (socially shared patterns of behavior and belief). Definisi substantif ini punya kelebihan bahwa ianya lebih spesifik daripada definisi fungsional. Lebih eksplisit tentang isi dari agama. Lebih sempit dan jelas daripada definisi fungsional. Definisi ini lebih tepat untuk mempelajari agama dalam masyarakat yang stabil tidak banyak perubahan. Namun, definisi ini akan mengalami kesulitan dalam penelitian tentang masyarakat yang berubah cepat, atau tentang perubahan agama, dan akibatnya akan menghasilkan pengertian yang berbeda tentang perubahan sosial.

Di pihak lain definisi fungsional memfokuskan perhatian kepada apa yang dibuat oleh agama bagi individu dan kelompok sosial. Disini isi dari kepercayaan dan praktik agama kurang penting. Contoh dari definisi fungsional yang tipikal adalah dari C. Geertz, yang mengatakan bahwa agama adalah “...(1) $a$ system of symbols which acts to (2) establish powerful, pervasive, and longlasting moods and motivations in men by (3) formulating conceptions of a general order of existence and (4) clothing these conceptions with such an aura of factuality that (5) the moods and motivations seem uniquely realistic" (Geertz 1966: 4). Agama adalah “(1) $a$ system of symbols," (2) yang punya fungsi psikologikal, (3) kultural, (4) sosial, (5) sehingga moods dan motivations itu nampak seolah-olah realistik. Jika dikaji latar belakang kelahiran definisi ini, maka dapat diduga bahwa definisi agama ini berasal dari aliran simbolik antropologi, yang berkembang di Departement of Social Relations di Harvard University, tahun 1950-70an, tempat Clifford Geertz membuat studi doktoralnya.

Berikut ini akan dibahas beberapa definisi agama yang telah dimajukan oleh para sarjana sosioantropologi. Kita mulai dengan definisi dari Milton Yinger (1957). Dikatakan oleh Yinger bahwa "Agama adalah pengetahuan kultural tentang sang supernatural yang digunakan oleh manusia untuk menghadapi masalah paling penting tentang keberadaan manusia di muka bumi ini" (Religion is the cultural knowledge of the supernatural that people use to cope with the ultimate problem of human existence). Substansi agama adalah pengetahuan kultural, jadi merupakan ciptaan manusia, bukan diturunkan dari Tuhan. Kedua, Raymond Firth mengatakan "Agama adalah satu seni kemanusiaan (a human art) yang mampu mencapai tingkat intelektual dan artistik terbesar, tapi juga mampu mencapai kerja manipulasi yang kompleks untuk memenuhi keperluan manusia yang percaya” (Firth 1996). Substansi adalah 
menurut Firth adalah seni kemanusiaan (human art).

Seterusnya adalah Wallace yang mengatakan "Agama adalah satu perangkat ritual, dirasionalisasikan oleh mitos-mitos, untuk menggerakkan kekuatan supernatural dengan tujuan untuk memperoleh, atau mencegah, dan mengubah keadaan manusia dan alam" (Religion is a set of rituals, rationalized by myth, which mobilizes supernatural powers for the purpose of achieving or preventing transformations of state in man and nature) (Wallace 1966). Substansi dari agama menurut Wallace adalah ritualritual (upacara) ciptaan manusia berasaskan atas mitos-mitos. Kelima adalah dari Tremmel yang mengatakan "Agama adalah cara-cara manusia berperilaku dalam usaha meng-hadapi aspek-aspek kehidupan manusia yang menakutkan dan tidak mampu untuk dimanipulasi." Cara-cara itu antara lain adalah dengan mengerjakan berbagai teknik intelektual, ritual dan moral (Tremmel 1976).

Seterusnya adalah definisi dari Haviland yang mengatakan, "Agama adalah kepercayaan dan pola tingkah laku, yang digunakan oleh manusia untuk menghadapi apa yang mereka pandang sebagai masalah-masalah penting yang tidak dapat diselesaikan dengan cara menggunakan teknologi atau teknik organisasi yang mereka punya. Untuk mengatasi kekurangan-kekurangan ini, manusia beralih ke perbuatan memanipulasi makhluk dan kekuatan supernatural" (Religion may be regarded as the beliefs and patterns of behavior by which humans try to deal with what they view as important problems that cannot be solved through the application of known technology or techniques of organization. To overcome these limitations, people turn to the manipulation of supernatural beings and powers) (Haviland 1996).
Substansi dari agama menurut Haviland adalah kepercayaan dan ritual yang tercipta karena keadaan manusia yang tidak berdaya dari segi teknologi dan organisasi. Contoh terakhir adalah definisi agama menurut Paul Radin (1957). Radin mendefinisikan agama sebagai kepercayaan kepada kekuatan-kekuatan adikodrati dan ritual yang berkaitan dengan kepercayaan tersebut. Hampir semua definisi di atas mengatakan bahwa agama adalah ritual (upacara) yang dilakukan atas dasar kepercayaan kepada makhluk atau kekuatan adikodrati. Jadi keimpulan akhir, substansi utama dari agama adalah ritual dan kepercayaan.

Substansi agama menurut definisi-definisi di atas adalah sesuai dengan definisi yang digunakan dalam berbagai agama, termasuk agama Islam. Dalam Islam, agama dipercayai terdiri dari dua unsur pokok, yaitu "beliefs" atau "kepercayaan" atau aqidah; dan "patterns of behavior" atau“ritual" atau syariah sebagai konsekwensi daripada aqidah tersebut. Dalam konsep Islam, kepercayaan atau aqidah adalah "rukun iman," sedangkan ritual atau syariah adalah "rukun Islam." Bagaimanapun, berbeda dengan anggapan sosioantropologi, berbagai agama samawi (agama wahyu) percaya bahwa agama bukan buatan manusia, tapi bersumber dari kebenaran-kebenaran yang berasal dari Tuhan yang diturunkan melalui malaikat kepada nabi-nabi, dan nabi-nabi meneruskan ajaran-ajaran ini kepada manusia. Agama bukanlah rekayasa yang ada dalam pikiran manusia tentang adanya kekuatan dan makhluk adikodrati.

Dengan demikian golongan agamawan tidak dapat menerima definisi sosioantropologi bahwa agama adalah ritual dan kepercayaan buatan manusia semata-mata. Definisi sosioantropologi di atas adalah definisi golongan yang tidak percaya kepada Tuhan, yaitu orang-orang yang tidak percaya akan adanya makhluk dan kekuatan adikodrati. Mereka berpikir 
secara rasional, logik dan objektif; bahwa segala sesuatu harus masuk akal dan dapat dibuktikan melalui panca-indera. Sesungguhnyalah bahwa sebagian besar sarjana-sarjana Barat yang ahli dalam kajian agama, terutama Freud adan Marx, di atas adalah orang-orang yang boleh disebut sebagai atheis.

\section{Sains vs Teologi}

Buku Darwin, The Origin of Species (1858) telah menimbulkan perdebatan besar dalam masyarakat Eropa, melahirkan pertentangan antara mereka yang percaya bahwa makhluk manusia adalah ciptaan Tuhan (theology) melawan mereka yang percaya dengan teori Darwin (sience) bahwa manusia bukan ciptaan Tuhan, tetapi adalah hasil dari proses evolusi makhluk-makhluk semenjak bumi terbentuk jutaan tahun yang lampau. Dalam kajian sosioantropologi pendukung kepercayaan yang pertama disebut pengikut teori kreasi, sedangkan yang kedua disebut pendukung teori evolusi. Pada abad ke 19 itu di Eropah, agama dengan asas teori kreasi, di satu pihak, dan sains dengan asas teori evolusi, di pihak lain, adalah dua bidang pemikiran yang tidak dapat diselaraskan. Masing-masing berjalan sendiri-sendiri.

Kajian terhadap agama di Eropa pada masa itu, yaitu terhadap agama Nasrani, hanyalah menggunakan pendekatan teologis yang dilakukan oleh para teolog. Kajian-kajian dibuat berasaskan pada dalil dan doktrin yang ada dalam kitab suci dan kisah-kisah para rasul. Apabila 13 tahun setelah buku Darwin Origin of Species, Edward Burnett Tylor dalam buku Primitive Religion (1871) dan James Frazer dalam buku The Golden Bough (1890) memperkenalkan agama-agama alamiah (natural religions) yang dianut oleh 'bangsa-bangsa primitif' secara jelas dan panjang lebar, masyarakat Barat melihatnya sebagai kepercayaan karut.
Agama-agama yang digambarkan oleh Tylor dan Frazer tersebut bukanlah agama. Agama yang benar-benar agama, ialah kepercayaan yang diwahyukan dari Tuhan, yaitu agama Nasrani seperti yang dianut oleh masyarakat Barat pada masa itu. Oleh karena itu, meski 'bangsa-bangsa primitif' itu punya kepercayaan keagamaan, tetapi dalam pandangan orang Eropah mereka tetap dianggap sebagai kaum kapir atau pagan.

Bagaimanapun, meski terus berada dalam keadaan perdebatan dan kontroversial, perhatian terhadap kajian-kajian agama secara ilmiah dengan menggunakan akal sehat (common sense) terus makin maju dan berkembang di Eropah. Dua puluh tahun setelah penerbitan buku Tylor, yaitu pada tahun 1891, seorang sarjana teologi Jerman yang bernama Müller, dalam The Gifford Lectures di the University of Glasgow (1891) mulai berani mengatakan di depan publik bahwa agama apa saja, termasuk agama alamiah atau Nasrani, dapat dikaji secara ilmiah (saintifik) (Müller 1892). Müller memperlihatkan bahwa kepercayaan kepada Tuhan (supernatural being) dapat dicapai oleh manusia dengan menggunakan akal sehat, tanpa merujuk kepada wahyu-wahyu yang tercantum dalam kitab-kitab suci. Manusia dapat sampai kepada pemikiran tentang adanya supernatural beings tanpa membaca atau belajar dari kitab-kitab suci Nasrani. Kajian terhadap agama yang seperti ini dapat dilakukan dengan menggunakan pendekatan historis, antara lain dengan mempelajari bukti-bukti yang dikumpulkan dalam the Sacred Books of the East.

Meski pernyataan Müller ini masih dianggap sebagai satu kerancuan pada masa itu, namun pernyataan itu dapat dipandang sebagai titik awal kemunculan satu ilmu baru dalam khazanah ilmu pengetahuan masyarakat Eropa, yaitu the Science of Religion, ilmu yang mempelajari agama bukan dari sudut 
pandang teologis tapi secara saintifik. Sebenarnya, dalam konteks perkembangan ilmu pengetahuan tentang agama di Eropa, Müller hanyalah pemukul gong saja tentang tanda bermulanya satu disiplin ilmu baru, karena pada masa itu pemikiranpemikiran saintifik tentang agama memang sedang berkembang marak di Eropa, sebagaimana diperlihatkan oleh buku-buku Edward B. Tylor dan James Frazer. Seperti rekan-rekan mereka dalam bidang ilmu-ilmu sains, para ilmuan tentang agama ini bekerja menurut metode sains modern, berdasarkan fakta dan bukti yang kuat, berusaha menarik kesimpulan-kesimpulan umum secara logik, membangun teori dan hipotesa yang dapat diuji secara benar, kemudian direvisi dan diperbaiki, untuk pada akhirnya menemukan kebenaran yang sejati tentang berbagai fenomena keagamaan. Itulah yang disebut sebagai the Science of Religion oleh Müller. Kemunculan ilmu tentang agama ini tentu sangat berkaitan dengan pemikiranpemikiran baru yang muncul sebagai dampak dari zaman Enlightenment di Eropa.

\section{Sains dan Teologi: Pemikiran Baiquni}

Percanggahan antara sains dan teologi mulai lahir ketika menentukan asal mula agama. Bagi sains, agama adalah kepercayaan dan ritual ciptaaan manusia, hanyalah semacam gagasan yang ada dalam pikiran manusia tentang makhluk dan kekuatan yang berkuasa di luar dirinya. Sains berasal dari Barat, hasil dari pemikiran yang lahir pada zaman enlightenment, bermula dari rasa tidak percaya (sceptical), berpikir secara rasional, logik, dan objektif. Segala sesuatu harus dapat dibuktikan secara objektif, melalui analisis rasional dan logik. Sebaliknya, teologi bermula dari rasa percaya secara subjektif (pasrah, yaqin). Bagi agamawan, khususnya agama wahyu, kepercayaan dan ritual itu adalah pernyataan dan suruhan (wahyu) dari tuhan. Begitu seseorang mengatakan tidak percaya kepada makhluk dan kekuatan adikodrati, maka hilanglah agamanya.

Seseorang yang percaya pada agama tertentu (agamawan) yang mempelajari agama dengan pendekatan sains harus menerima kenyataan bahwa dia sedang berada dalam keadaan dilematis, dia menerima kedua prinsip yang bertentangan di atas dalam waktu yang sama. Di satu pihak, dia menerima agama sebagai bagian dari system of knowledge (sains) berarti menerima kebenaran sosial dari agama; bahwa agama itu dianut oleh sebagian besar manusia; bahwa agama itu telah mempengaruhi secara signifikan perilaku manusia, baik secara individual maupun secara komunal. Bagaimanapun, penerimaan itu hanya sampai di otak pikiran untuk kepentingan keilmuan. Menerima agama sebagai kenyataan sosial seperti di atas tidak sama dengan "percaya" tentang kebenaran doktrindoktrin keagamaan sesuatu agama. Seorang ilmuan sosioantropologi dapat menerima kebenaran sosial dari fenomena keagamaan, tetapi tidak perlu menerima kebenaran doktrin sesuatu agama, karena dia selalu berpikir secara saintifik, yaitu objektif dan logik. Tidak adakah jalan untuk menyelaraskan kedua pandangan yang berlawanan ini? Bagaimanakah cara menyelesaikan masalah dilematis ini?

Berkaitan dengan masalah di atas, yaitu dilema antara pandangan sains dan pandangan teologi, di bawah ini akan disajikan dua definisi ilmu dari dua tokoh ilmuan yang berbeda aliran. Pertama adalah dari Carlo Lastrucci yang beraliran positivist-materialist, sedangkan yang kedua adalah dari A. Baiquni yang beraliran positivist-spiritualist-Islam. Menurut Carlo Lastrucci, ilmu (sains) adalah "an objective, logical, and systematic method of analysis of phenomena, devised to permit the 
accumulation of reliable knowledge" (dikutip dalam Pelto \& Pelto 1978). Jadi ilmu bukanlah satu himpunan pengetahuan, tapi satu metode analisis tentang suatu fenomena: fenomena alam, sosial, atau kemanusiaan. Analisis terhadap fenomena ini harus dilakukan secara objective (harus didukung oleh bukti materi, data, fakta dan lain-lain yang dapat dikenali dengan pancaindera orang secara umum), harus logis atau logical (harus masuk akal, harus dengan nalar, rasio), dan harus sistematis (dilakukan dengan prosedur yang jelas, teratur, dan tersusun sehingga analisis dapat diulang oleh orang lain). Lawan dari objektif adalah subjektif, artinya fakta tidak dapat dikenali oleh pancaindera orang banyak, hanya dapat dikenali oleh individuindividu tertentu saja. Lawan dari logis adalah tidak logis, atau tidak nalar, tidak dapat dibuktikan secara material. Lawan dari sistematik adalah khusus, ideosyncratic, hanya dapat dilakukan satu kali, hanya dapat dilakukan oleh orangorang tertentu saja, orang lain tidak dapat mengulanginya. Terakhir, pekerjaan menganalisis fenomena ini dilakukan untuk menghasilkan kesimpulankesimpulan yang dapat dipercaya, sedemikian rupa sehingga bertambah dan berkembanglah ilmu itu (cummulative knowledge). Contohnya, bahwa nabi Isa al Masih lahir tanpa ayah, tidak dapat dipercayai oleh sains, karena manusia selalu terbentuk atas pertemuan sperma (lelaki) dan indung telur (perempuan). Kepercayaan ini adalah tidak objektif, tidak logik, dan tidak konsisten.

Almarhum A. Baiquni mengatakan bahwa dalam tradisi ilmu alam (science) metode analisis ini dijalankan dengan cara melakukan observasi (pengamatan) dan pengukuran terhadap gejala-gejala alam, kemudian barulah dilakukan analisis, dan seterusnya diambil kesimpulan yang dapat diterima secara nalar (rasio, logika) (Baiquni 1983). Seluruh proses dalam metode keilmuan ini, yang dilakukan secara prosedural, mulai dari pengamatan, pengukuran, analisis sampai kepada penarikan kesimpulan oleh Baiquni disebut dengan istilah "intizhar." Kata "intizhar" dalam bahasa Arab dalam al-Qur'an yang berdekatan dengan kata "intazhara" dan "nazhar." "Intazhara" dalam bahasa Inggeris berarti "to scrutinize, to look closely at," atau "to expect, to look forward to, to anticipate." Nampaknya definisi "science" dari Lastrucci hampir sama dengan definisi "intizhar" dari Baiquni, yaitu metode penelitian (to scrutinize) dengan menggunakan pengamatan, penggolongan, perbandingan, pengukuran, dan analisis untuk mencapai suatu kesimpulan, yang dilakukan secara nalar, logik, atau masuk akal.

Bagaimanapun, ada satu hal penting yang tidak disebut Baiquni sebagai syarat dalam intizhar, yaitu sifat "objective" dari metode tersebut (Baiquni 1983: 2). Karena, berbeda dari ilmuan Barat yang hanya mengakui satu alam, yaitu alam fisik, Baiquni mengakui adanya alam lain selain alam fisik, yaitu alam ghaib, yang hukumhukumnya dikuasai oleh Allah, dan sebagian dari hukum itu telah diturunkan Allah kepada nabi Muhammad dalam alQur'an. Bagi Baiquni, fenomena alam tidak seluruhnya bersifat kebendaan yang faktanya dapat ditangkap dengan pancaindera (objective). Sebagian dari fakta itu adalah bersifat ghaib dan tidak dapat ditangkap dengan pancaindera. Misalnya, bagi ilmuan Eropa, peristiwa isra' dan mi'raj adalah peristiwa ghaib. Ini adalah peristiwa yang tidak masuk akal, tidak dapat diselidiki secara ilmiah, tidak dapat diulang, tidak dapat diamati, idak dapat diukur, dan tidak dapat dibuktikan secara objektif. Sebaliknya, bagi Profesor fisika Baiquni yang Islam, kedua perjalanan nabi Muhammad itu (isra' dan mi'raj) adalah nyata dan benar, seperti nyata dan benarnya perjalanan austronot Barat ke ruang angkasa. Namun berbeda dengan perjalanan austronot yang terjadi di dunia fisik, maka perjalanan nabi 
Muhammad terjadi di dunia non-fisik, terjadi di alam lain yang hukum-hukumnya tidak perlu sama dengan hukum-hukum yang ada di alam fisik. "Maha Suci Allah, yang telah memperjalankan hambaNya pada waktu malam dari Masjidil Haram ke Masjidil Aqsha yang telah Kami berkahi sekelilingnya, untuk Kami perlihatkan kepadanya sebagian dari tanda-tanda (kebesaran) Kami. Sesungguhnya Dia adalah Maha Mendengar dan Maha Mengetahui" (al-Isra': 1). Menurut orang yang percaya, termasuk Baiquni, nabi Muhammad diperjalankan oleh Allah dalam keadaan sehat dan waras, tidak dalam keadaan sekarat koma hampir mati. Muhammad adalah orang yang jujur. Ucapannya adalah benar. "Kalau Muhammad yang mengatakan itu, aku percaya," demikian ditegaskan oleh Abu Bakar, khalifah pengganti Muhammad.

Adanya alam lain di luar alam fisik dicontohkan oleh Baiquni dengan fenomena gelombang elektromagnetik seperti halnya gelombang radio, televisi, radar, dan sebagainya. Gejala ini adalah nyata dan ada meski tidak dapat dibuktikan keberadaan dan sifatnya secara objektif melalui pancaindera (Baiquni 1983: 87). Alam bukan-fisik ini disebut orang dengan istilah metafisik. Bagaimanapun, hal yang masih menjadi tanda tanya kini adalah tentang kaitan antara "logic" dari Lastrucci dengan "nalar” (rasio) dari Baiquni. Apakah sama, atau berbeda? Atau ada penjelasan lain? Bagi Baiquni, sama dengan Lastrucci, intizhar adalah menggunakan akal dan pikiran, jadi harus logik, sebagaimana disebutkan surat Junus: 101:

"Katakanlah (hai Muhammad): perhatikanlah dengan intizhar/nazhar apaapa yang ada di langit dan di bumi."

Ayat ini bagi Baiquni adalah suruhan bagi orang Islam agar menggunakan akal, logik, nalar dalam mengamati (menyelidiki) semua hal yang ada di bumi dan di langit.
Dari seluruh uraian di atas, nampak terkesan bahwa Baiquni berada dalam dua "kepercayaan." Di satu pihak, sebagai ilmuwan, beliau percaya kepada fenomena alam fisik yang objektif yang bergerak menurut hukum-hukum alam, yang harus dianalisis secara logik dan nalar (intizhar). Baiquni mengakui, karena sifatnya yang terbuka kepada umum, maka teori-teori ilmu alam yang telah diterima secara umum adalah konsensus atau mufakat dari seluruh masyarakat ilmuwan. Tapi di pihak lain, sebagai Muslim, beliau percaya akan adanya alam ghaib (metafisik) dengan hukum-hukum tersendiri yang berbeda dari hukum alam fisik, dan karena itu untuk menganalisis fenomenanya berada di luar jangkauan nalar akal ini. Beliau percaya adanya kondisi yang di luar batas akal, tidak mampu dinalar oleh akal biasa, karena kemampuan akal adalah terbatas. Hasil kerja nalar akal dengan bukti-bukti yang objektif menurut pancaindera tidak menghasilkan kebenaran mutlak, tapi relatif. Kayu standar, alat ukur panjang, atau standar sukatan, atau standar timbangan, dapat berubah karena perbedaan suhu. Apa yang terlihat sebagai benda padat tidak bergerak, sebenarnya adalah terdiri dari massa elektron yang sangat halus yang berputar dengan cepat mengelilingi pusat atom.

Bagaimanapun, sebelum sampai kepada kerja analisis tersebut diperlukan satu kepercayaan tersendiri, satu keyakinan tentang adanya alam ghaib dengan hukumhukum tersendiri, yang berada di luar batas akal, yang hukum itu sebagian besar berada di tangan Tuhan, dan sebagian lain sudah diturunkan kepada para nabi dan terbaca dalam al-Qur'an (Baiquni: 88-89). "Dan mereka bertanya kepadamu tentang roh. Katakanlah: roh itu termasuk urusan Tuhanku, dan tidaklah kamu akan diberi pengetahuan mengenainya kecuali sedikit saja" (al-Isra'-85). Sebagai seorang muslim yang melakukan intizhar dan mengembangkan sains, Baiquni yakin bahwa al-Qur'an adalah wahyu yang asli. 
Dalam penyelidikannya, beliau telah menemukan berbagai gejala dan hukum alam semesta yang sama dengan yang disebutkan dalam ayat-ayat al-Qur'an. Beliau mengetahui bahwa penemuanpenemuan gejala dan hukum alam yang dibuat ilmuan-ilmuan Barat pada masa akhir-akhir ini ternyata sudah tersurat dalam al-Qur'an yang diturunkan Allah kepada nabi Muhammad 14 abad sebelumnya.

Menurut Al-Abdali, sekitar satu per lima dari seluruh ayat dalam al-Qur'an adalah bersifat saintifik (berkaitan dengan ilmu pasti-alam), dan ayat-ayat ini tidak pernah ditafsirkan oleh nabi Muhammad (alAbdali 2008: 4). Ayat-ayat itu tidak mungkin dapat ditafsirkan dengan benar pada zaman tersebut, karena tingkat ilmu pengetahuan manusia ketika itu masih cetek. Ibnu' Abbas adalah benar ketika beliau enggan untuk menafsirkan seluruh isi al-Qur'an. Beliau tidak mau memberikan pendapat tentang bagian dari isi kitab Allah yang tidak diketahuinya. Hanya Allah yang tahu bila masanya suatu ayat dapat ditafsirkan dan dipahami maknanya dengan sempurna oleh manusia. Karena itu Baiquni yakin akan adanya alam lain kecuali alam fisik yang kita hidupi ini. Adanya alam lain ini dibuktikan melalui pengalaman orang-orang tertentu yang pernah sekarat atau koma hampir mati. Dalam keadaan koma itu, mereka bercerita melihat dirinya keluar dari badan jisimnya, melihat anggota keluarganya dan dokter sedang melakukan sesuatu kepada badan jisimnya. Kemudian mereka masuk ke sebuah ruang gelap dengan cahaya gemerlap tampak jauh, di mana mereka berkomuniskasi dengan makhluk tanpa sosok. Di ujung perjalanan ini, mereka minta sendiri, atau di suruh oleh makhluk ghaib itu, untuk kembali ke dunia fana kerana masih ada tugas yang harus diselesaikan (Baiquni 1983: 94). Baiquni percaya bahwa tuhan Allah menyuruh umatnya untuk selalu belajar dari alam dengan menggunakan akal pikiran waras.

\section{Sains dan Agama Menurut Vivekananda.}

Kini, kita beralih ke ajaran Hindu India. Berikut adalah ringkasan dari tulisan Swami Ranganathananda tentang gabungan antara sains dan agama menurut Vivekananda (Ranganathananda, 1964). Vivekananda menyatakan bahwa sains dan agama adalah dua disiplin ilmu. Ia tidak melihat agama sebagai kepercayaan saja, tapi juga sebuah ilmu. Jika kedua jenis ilmu ini dikombinasikan akan menghasilkan wujud menyeluruh tentang genius manusia. Namun dalam beberapa abad terakhir hubungan keduanya tidak harmonis. Barulah pada abad ke 20, pendekatan baru muncul untuk menghubungkan kedua ilmu manusia ini. Sains dan agama dapat saling merangkul tanpa menganggu sifat masing-masing, dan bekerja demi kemaslahatan manusia. Makin disadari bahwa ada elemen sains yang dapat diterima oleh agama, dan sebaliknya ada elemen agama yang dapat memperkuat sains. Spiritualis agung Swami Vivekananda telah berhasil membawa sistesis kedua jenis ilmu ini. Dikatakan oleh Romain Rolland, "tentang equilibrium dan synthesis maka pemikiran konstruktif Vivekananda perlu dicatat. Beliau merangkum semua jalan spirit: empat yoga secara keseluruhannya, ucapan-ucapan dan ibadah, seni dan sains, agama dan upacara, dari yang paling spirit sampai ke yang paling praktikal... Beliau adalah perwujudan dari keharmonisan seluruh energi manusia.”

Peradaban yang kita hidupi masa kini adalah hasil dari sains, sains murni dan sains terapan. Ilmu pengetahuan membawa kepada kekuasaan, dan kekuasaan membawa kepada pengawasan dan manipulasi kekuatan-kekuatan alam, membuat manusia mampu menentukan kondisi kehidupan dan lingkungannya. Setiap hasil penyelidikan sains murni diubah menjadi sains terapan, hasilnya membuat manusia mampu mengontrol dan 
memanipulasi kekuatan alam. Demikianlah kekuatan dari hati manusia. Namun demikian, kalau kita mendalami sains lebih jauh, akan terlihat keterbatasan dan kekurangannya. Perubahan waktu dan penemuan-penemuan baru terus mengubah rumus-rumus dan hukum-hukum sains yang lama. Apa yang baru dan pasti pada abad yang lalu menjadi satu hal yang dangkal bila dibandingkan dengan penemuan-penemuan baru pada masa kini. Sains sampai hari ini baru menemukan halhal yang di permukaan saja, belum sampai menyentuh kenyataan yang ada jauh di bawah permukaan itu. Baru kulit luarnya. Sains bergulat dengan fenomena yang dapat dikesan oleh panca indera dan peralatan bantuan bagi lebih memberdayakan pancaindera tersebut. Terlalu sedikit realitas yang dapat dikesan oleh pancaindera dan peralatan itu, dan di belakangnya terdapat tanda-tanda tentang adanya sesuatu yang menentukan dan mengontrol ralititas tersebut. Di belakang alam yang dapat dikesan ini terdapat alam yang tidak dapat dikesan. Ini adalah kenyataan tentang keterbatasan sains dan metode-metodenya. Hal ini berlaku bagi ilmu fisik maupun ilmu biologi.

Sementara itu di pihak lain, agama juga telah menderita serangan dari pemikirpemikir revolusioner dan idealist seperti Karl Marx. Melihat Eropa zaman revolusi industri, Marx bertanya: Jika Tuhan itu ada, mengapa Dia membiarkan saja begitu banyak penderitaan di dunia, jutaan orang kelaparan dan anak-anak bekerja sebagai budak dipabrik-pabrik? Agama menurut Marx adalah "jiwa yang tanpa jiwa, hati dari sebuah dunia tanpa hati, candu bagi manusia." Hasil dari semua ini, pada akhir abad ke 19, agama dan kepercayaan terhadap Tuhan dan akhirat kehilangan kekuatan dalam peradaban modern. Manusia tidak takut lagi kepada Tuhan, apalagi kepada malaikat. Sains modern memandang agama pada tahap awal sebagai kekhilafan yang berbahaya dan pada akhirnya menjadi khayalan yang menyakitkan. Bagaimanapun, setelah dua kali Perang Dunia, ilmuan mulai sadar bahwa mereka tidak mempunyai obat yang meyakinkan tentang penyakit dunia. Ilmu yang mereka punyai tidak mencukupi. Dikatakan oleh Einstein: "Sains dapat mengurai plutonium, tapi dia tidak dapat mengurai setan yang ada di dalam hati manusia.” Sains tidak mampu membuat manusia bahagia dan terpuaskan. Ini adalah bidang disiplin ilmu lain, yaitu ilmu tentang hakikat dalaman manusia, itulah agama menurut pengertian filsafat India.

Keperluan kita sekarang, menurut Vivekananda, ialah melihat sains dalam sudut pandang pengetahuan dan kesejahteraan manusia secara menyeluruh, di mana sumbangan keagamaan Dunia Timur dan sumbangan sains Dunia Barat saling melengkapi secara harmonis. Dunia spirit Timur adalah sama riilnya dengan dunia sains Barat. Atau dalam cemoohan yang terbalik, Barat melihat Timur yang spiritual sebagai pemimpi, Timur pun melihat Barat yang sains sebagai pemimpi. Alam semesta ini adalah sebuah misteri bagi orang primitif; keadaan ini tidak berubah bagi manusia beradab bahkan sampai abad ke 20 ini. Dengan penemuanpenemuannya, ahli sains baru sampai mencakar permukaan alam semesta, masih jauh dari jantung masalah alam semesta. Jika misteri alam semesta telah membuat bingung ahli sains, maka misteri manusia lebih membingungkan lagi. Yang dikuasai manusia baru pengetahuan tentang bentuk struktur, belum tentang isinya. Sudah waktunya sains memberikan perhatian pada usaha untuk membuka misteri ini.

Apakah hakikat dari manusia itu? Manusia mungkin satu bintang yang tersesat. Manusia adalah mesin tubuh yang rumit: makan, bicara, tertawa, dan akhirnya mati bila waktu menekan sakelar lampunya ke bawah. Bagaimanapun, mari diingat bahwa kita adalah "benda" yang mempertanyakan hal itu. Kita adalah subjek utama, tidak bisa direndahkan menjadi dimensi objek. 
Kitalah the oberver, the knower, the seer. "Siapakah saya?" Secara fisik saya hanyalah sebuah debu yang sangat kecil di dalam alam semesta yang luas ini. Namun, melalui pikiran, saya memahami alam semesta ini. Saya dapat melipat alam yang luas ini ke dalam satu formula yang diberikan oleh kekuatan dan penetrasi pikiran saya.

Manusia tidak dapat disederhanakan sebagai jasad semata, atau material semata. Di dalam dirinya terdapat sesuatu yang transendental, yang tidak dapat disederhanakan. Dia adalah the self, yaitu yang utama, aspek yang tidak dapat dipisahkan. Sains kalau mau maju seterusnya, harus menyelidiki bidang misteri ini, yaitu misteri tentang hal di luar alam semesta. Ini bidang kajian yang luas, bidang tentang kesadaran manusia, ego manusia, manusia sang subjek bukan sang objek. Manusia adalah pencipta sains, teknologi, budaya dan peradaban; yang pada masa kini adalah juga satu-satunya kemungkinan yang akan menghancurkan peradaban yang diciptanya itu. Manusia adalah pemain sekaligus penonton dari drama keberadaannya dalam alam semesta ini. Dia hanya memahami sedikit tentang proses organik, bahkan lebih sedikit lagi tentang kemampuan uniknya dalam melihat, menalar dan membayangkan alam sekelilingnya. Hal yang paling tidak diketahuinya adalah tentang kemampuannya dalam men-transend dirinya dan memahami dirinya sendiri.

Dalam pemikiran India, dalam Vedanta, tugas agama adalah melakukan penyelidikan tentang misteri pengalaman, yaitu hal yang diabaikan oleh sains. "Man the Unknown, manusia sebagai subjek dari pengalamannya sendiri, adalah lapangan pengkajian tersendiri. Kata Vivekananda: "Pencarian yang sebenarnya adalah tentang hal yang di luar kesadaran. Kesadaran terikat dengan deria (panca indera). Di luar itu, di luar deria itu, manusia harus menyelaminya, dalam rangka untuk sampai pada kebenaran-kebenaran dunia spiritual, dan di sana muncullah manusia yang disebut resi (seers of thought), yaitu manusia yang berhadapan dengan kebenaran-kebenaran spiritual.” Pemikiran India mempercayai agama dan sains sebagai disiplin-disiplin ilmu yang valid dalam mencari kebenaran. Tidak seperti teologi Barat, pemikir India tidak mempertentangkan agama dengan sains, karena kedua-duanya bertugas mencari kebenaran yang tersembunyi di belakang alam semesta, di dalam data yang terungkap dalam eksperimen yang dikesan melalui panca indera (deria).

Di pihak lain, sains Barat tidak terbungkus dalam kumpulan fakta-fakta tertentu, terikat pada departemen tertentu, atau dengan metode penyelidikan tertentu; tapi satu sikap intelektual, satu pemikiran kritis yang penuh keyakinan, yang menerima kesimpulan hanya kalau didukung oleh bukti. Dua ciri utama dari metode sains adalah objektifitas dan ketepatan (objectivity and precision). Dalam konteks ini, satu sains tentang agama-sains tentang fakta-fakta dunia dalaman manusia, ialah menjadi a science of far-reaching significance. Agama sebagaimana yang dipahami Barat adalah bertentangan dengan semangat pencarian dan penyelidikan yang rasional. Agama adalah satu dogma atau doktrin, satu pemikiran yang beku, dan satu yang harus diyakini oleh manusia.

Di India, sebaliknya, agama selalu diartikan sebagai sesuatu pencarian, penemuan, dan pengujian, bagai satu cabang dari sains. Hal ini dijumpai dalam kitab klasik Upanisad dan tulisan kontemporer Vivekananda. Kata Vivekananda: "Kita semua tahu teori-teori tentang kosmos sesuai dengan ilmu astronomi dan fisika moderen, dan pada saat yang sama mereka menertawakan teologi Eropah. Penemuan-penemuan ilmiah ini telah menjadi bom yang menghancurkan kepercayaan agama yang 
dianut teologian Eropa, sebaliknya para teologian selalu merendahkan nilai hasil penyelidikan ini.” Ketika agama menolak bantuan nalar, sebenarnya dia melemahkan dirinya sendiri.

Dasar pemikiran agama yang berlaku umum adalah kepercayaan. Percaya karena hal itu tertulis dalam kitab suci, karena diajarkan oleh Kiyai atau Pendeta, karena orang lain juga percaya. Tapi kepercayaan yang semacam ini tidak menggalakkan berpikir. Agama yang semacam ini boleh disebut sebagai "tidak berpikir dengan teliti” (not-thinking-carelessness). Padahal metode penelitian sains harus juga digunakan dalam sains tentang agama. Hal ini tidak hanya akan membuat agama itu scientific, tapi juga membuat agama makin kuat, karena sains tidak mempunyai kewajiban dalam memberi garansi dalaman tentang kebenarannya, tapi agama punya. Jika sebuah agama kemudian dihancurkan oleh hasil metode penelitian tersebut, maka agama tersebut hanyalah semacam kepercayaan kepada hantu saja (superstition).

Pengalaman adalah satu-satunya sumber pengetahuan. Di dunia ini, agama adalah satu-satunya sains yang tidak mengenal kepastian (surety), karena agama tidak diajarkan sebagai sains tentang pengalaman. Namun ada sebagian orang yang mengajarkan agama dari pengalaman, yaitu kaum mistikus (mystic). Mistikmistik ini dalam setiap agama berbicara dengan lidah yang sama dan mengajarkan kebenaran yang sama. Inilah sains agama yang sesungguhnya. Agama ialah berurusan dengan kebenaran dalam dunia metafisik, sebagaimana fisika dan kimia berurusan dengan kebenaran dalam dunia fisik. Buku pelajaran kimia adalah buku ilmu alam. Buku untuk belajar agama adalah minda dan hati kita. Belajar hanya satu buku saja, sains saja, atau agama saja, adalah tidak memuaskan. Begitu juga belajar tentang yang satu dengan dasar yang lain adalah tidak cukup. Tapi belajarlah yang satu dengan cahaya dari kesimpulan-kesimpulan yang diperoleh dari yang lain.

Kata Vivekananda: “Ada dua dunia: mikrokosmos dan makrokosmos, internal dan eksternal. Kita mendapatkan kebenaran dari keduanya dengan cara pengalaman. Dari pengalaman internal kita mendapatkan psikologi, metafisik, dan agama, dari pengalaman eksternal kita mendapatkan ilmu-ilmu fisika. Kebenaran yang sempurna seharusnya adalah dalam harmoni pengalaman dalam kedua dunia ini." Metode penelitian dalam kedua jenis ilmu ini adalah sama: pengumpulan data, klasifikasi data, analisis objektif untuk mencari hukum-hukum di belakangnya, dan terakhir adalah aplikasinya untuk perbaikan penyakit-penyakit manusia dan peningkatan dan pengkayaan kehidupan manusia. Cara pelajaran agama yang seperti inilah yang diwariskan oleh pemikir-pemikir India klasik. Dengan dasar kekerasan semacam berlian ini (adamant), spiritualitas India tidak dapat termakan zaman.

Semangat Vedantik yang tulen tidak dimulai dengan satu sistem pemikiran awal yang sudah tercetak. Spirit ini mempunyai kebebasan absolut dan keberanian yang tak terlawan dibanding dengan berbagai agama berkenaan dengan fakta-fakta yang harus diamati dan berbagai hipotesis yang dibangun untuk koordinasinya. Tidak pernah terhambat oleh birokrasi kependetaan, setiap orang bebas untuk mencari apa yang disukainya bagi penjelasan spiritual tentang alam semesta yang dilihatnya. Manusia, menurut hakikat alamnya, ialah ilahi; di belakang manusia yang kerdil itu ialah Atman, selalu bebas, selalu murni, selalu sempurna. Tubuh, minda, dan ego hanyalah bagian eksternal dari manusia yang sesungguhnya yang tidak mati dan ilahiah. Dasar manusia yang lain adalah Brahman, totalitas dari Diri dan Bukan-diri, yang bercirikan sebagai kebenaran, kesadaran, dan Infinity. 
Di dalam Mundaka Upanisad, terbaca percakapan seperti ini: Apakah realitas itu? Apakah masih ada realitas yang unik kalau kita sudah mengetahui perwujudan semua alam semesta? Apakah ada kesatuan di belakang keanekaragaman? Jawabannya: ada jenis pengetahuan yang diperoleh manusia, yaitu pengetahuan tinggi dan pengetahuan rendah. Keduanya hanya diselidiki. Pengetahuan rendah terdiri dari kitab Veda suci, phonetic, tatacara ritual, grammar, etymology, prosody, dan astronomy. Semua ini merangkum bukubuku suci, literature, seni, sejarah, dan sains. Kitab-kitab suci hanya memberi kita informasi mengenai Tuhan, bukan Tuhan itu sendiri. Pengetahuan tinggi adalah para, dengan mana semua hal yang abadi (imperishable) dinyatakan. Sementara itu sains dan lain-lain adalah berubah, jadi tidak abadi (perishable).

Menurut Veda, manusia adalah spirit yang tidak dilahirkan dan tidak musnah, tidak pernah lahir dan tidak pernah mati. Manusia adalah the Infinite, the Omnipresent, the Omniscient. Akhir dan tujuan dari agama, menurut pemikir klasik India, adalah mengalami Tuhan, atau anubawa, melalui pertumbuhan yang mantap dalam kesadaran spiritual manusia (Ingat Syekh Siti Jenar). Inilah tonggak dasar dari agama. Yang musnah adalah tubuhnya. Tapi spiritnya tetap hidup. Dia akan hidup di dalam tubuh yang lain (reinkarnasi). Seperti apa tubuhnya kemudian, tergantung kepada kualitas kehidupannya sebelumnya. Kalau baik, dia akan hidup dalam tubuh yang lebih baik. Kalau jahat, dia akan hidup dalam tubuh yang lebih buruk, bahkan dalam bentuk binatang.

Bila kita menjalani kehidupan keagamaan, kekuatan datang kepada kita, kesadaran makin besar, simpati tumbuh dan meluas, dan kita merasa bahwa kita sedang menuju menjadi manusia yang lebih baik. Jika agama hilang dari masyarakat, yang tinggal hanyalah barbarisme. Peradaban klasik dimusnahkan oleh barbarisme yang datang dari luar. Tapi peradaban modern akan dimusnahkan oleh barbarisme yang tumbuh di dalam diri peradaban itu sendiri. Yang akan menyelamatkan kita adalah agama, yang mengajarkan cinta dan keikhlasan (altruisme). Agama, kata Vivekananda, ialah perwujudan keilahian yang sudah ada dalam diri manusia.

\section{Kesimpulan tentang Sains dan Agama.}

Menurut kedua pendapat di atas, tidak ada konflik antara agama dengan sains. Masing-masing saling mengisi, saling menolong. Di atas adalah kutipan dua pemikiran tentang sintese kajian sains dengan kajian agama. Sebenarnya ada banyak kajian-kajian yang mengupas tentang sinkronisasi antara sains dengan agama, seperti buku-buku karangan John F. Haught (2004), Hj. Othman \& Yussof (2009), Russell (1979), dan Kartanegara (2005). Dalam agama, setiap jiwa punya potensi ilahi. Tujuan agama adalah mewujudkan keilahian ini dalam mengontrol alam, internal maupun eksternal. Sementara itu, doktrin atau dogma, ritual, buku suci, rumah ibadah, adalah rincian kedua dari agama. Sintese agama dengan sains adalah sintese hati dengan otak. Kita ingin membawa cahaya intelektualitas bergabung dengan hati yang penuh dengan cinta, ikhlas dan syukur. Gabungan ini akan memberi kita filsafat paling tinggi. Inilah agama pada masa yang akan datang.

\section{Fungsi-fungsi Agama.}

Selanjutnya, secara umum sosioantropologi berpendapat bahwa agama mempunyai fungsi dalam kehidupan manusia. Kajian fungsional tentang agama sangat menekankan hal ini. Beberapa fungsi spiritual dari agama yang disebutkan dalam berbagai definisi tentang agama adalah:

- Memberikan makna tertinggi (the provision of ultimate meaning), 
- Usaha untuk menafsirkan hal yang tak diketahui dan mengontrol hal yang tak terkontrol (the attempt to interpret the unknown and to control the uncontrollable),

- Personifikasi dari pemikiran-pemikiran manusia (personification of human ideals)

- Integrasi dari kultur dan legitimasi dari sistem sosial (integration of the culture and legitimation of the social system)

- Projeksi dari makna-makna kemanusiaan dan pola sosial kepada suatu entitas yang maha kuat-maha tinggi (projection of human meanings and social patterns onto a superior entity), dan

- Usaha untuk menangani masalahmasalah utama dalam kehidupan manusia di muka bumi (the effort to deal with ultimate problems of human existence).

Disamping fungsi spiritual di atas, agama juga dikaitkan dengan fungsi-fungsi yang lain dalam kehidupan manusia. Di bawah ini diberikan contoh-contohnya oleh O'dea (1969: 13 - 18) dan Lessa \& Vogts (1979: $36-79)$.

\section{Fungsi Undang-undang.}

Agama menentukan mana tingkah laku yang salah dan mana yang benar. Yang salah akan dihukum, masuk neraka, dan yang benar akan diberi anugerah, masuk sorga. Agama telah menjadi undangundang yang mengatur tingkah laku manusia. Sang Maha Kuasa selalu menjaga dan memerhatikan umatnya, mengadili mereka dalam satu mahkamah muktamad di akhirat. Yang berdosa masuk penjara neraka. Yang benar masuk ke dalam taman sorga.

\section{Fungsi Meringankan Beban Hidup.}

Agama mengambil alih beban dalam membuat keputusan-keputusan penting dalam kehidupan, dari diri individu manusia ke Sang Maha Kuasa. Apabila manusia menghadapi beban hidup yang berat maka mereka akan menghadap dan berserah diri kepada Tuhan, Yang Maha Kuasa, Yang Maha Penolong, Yang Maha Penyayang, Yang Maha Permurah, dan seterusnya. Dalam agama Islam dikatakan, antara ciri khas orang beriman ialah saat ia dirundung malang, maka ia segera kembali kepada Yang Maha Pemurah lagi Maha Penyayang, Allah Subhaanahu wa ta'aala. Ia segera mengingatNya (dzikrullah) dan memanggil-Nya. Sebab ia tahu bahwa hanya dengan mengingat dan memanggil Allah sajalah hati akan memperoleh ketenteraman. Tidak ada tempat lain yang patut dijadikan muara pengaduan selain kepada Rabb, Pencipta, Pemilik, Pemelihara dan Penguasa kehidupan ini.

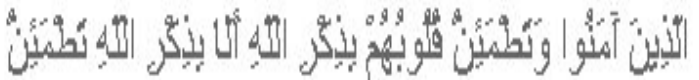 بgin}

"Orang-orang yang beriman dan hati mereka menjadi tenteram dengan mengingat Allah. Ingatlah, hanya dengan mengingati Allah-lah hati menjadi tenteram.” (QS Ar-Ra'du ayat 28)

\section{Fungsi Psikologis.}

Semua agama mempunyai sejumlah fungsi psikologi dan sosial penting. Agama mengurangi dan mengobati rasa kuatir dengan cara memberi penjelasan tentang hal-hal yang tidak diketahui dan membuat hal-hal itu dapat dipahami. Bila kita kuatir dan stress akan masa depan, tentang ujian, tentang pekerjaan, tentang apa saja. Mari berserah diri kepada Yang maha kuasa.

\section{Fungsi Tradisi Lisan.}

Melalui ritual, bacaan-bacaan, dan mitologi, agama berfungsi dalam meningkatkan pembelajaran tentang tradisi lisan. Cerita tentang para rasul dan sahabat nabi-nabi, tentang raja yang adil, tentang orang-orang suci, tentang seorang 
perempuan yang tegar dengan imannya meski diancam bunuh oleh raja kafir, dan lain-lain.

\section{Fungsi Memberi Kenikmatan.}

Agama juga memberi rasa menyenangkan dengan cara mempercayai bahwa pertolongan Sang maha kuasa selalu akan datang bila manusia berada dalam keadaan susah dan bahaya. Berdoalah kepadaKu, maka akan Aku kabulkan doamu.

\section{Fungsi Menjaga Solidaritas.}

Terakhir, agama memainkan satu peranan penting dalam menjaga solidaritas sosial. Persatuan umat dan gereja. Saling tolong saling kasih sesama manusia, apalagi sesama agama. Fungsi ini sangat ditekankan oleh Durkheim dan Malinowski, dan dikritik oleh Geertz dalam makalah "Ritual and Social Change: A Javanese Example.”

\section{Tujuan Mempelajari Agama Secara Sosioantropologis.}

Nyatanya yang banyak dipelajari sosioantropologi tentang agama adalah tentang kepercayaan dan ritual masyarakatmasyarakat primitif. Mengapa kita belajar tentang agama orang-orang primitif? Untuk apa sosioantropologi mempelajari semua konsep, ideas, dan praktek-praktek keagamaan orang zaman dulu ini (natural religions), karena pada masa kini hampir semua orang menganut agama wahyu (revealed religions) (Judaisme, Kristianiti, Islam, Hinduisme, Buddhisme, dan Jainisme, dan lain-lain). Agama orang dulu ini tinggal sangat sedikit penganutnya, dan tidak lama lagi akan hilang dari muka bumi. Atas keragu-raguan saya tersebut, maka di bawah ini dikutipkan jawaban seorang antropolog besar dari Inggris, Evans-Pritchard. Pertama, kata EvansPritchard, “... orang-orang yang telah bertanggung jawab dalam mengubah seluruh suasana pola pikiran dalam peradaban kita masa terakhir ini, adalah para pencipta mitologi terbesar, yaitu Darwin, Marx, Engels, Freud, dan Frazer (dan boleh ditambah dengan yang lain). Semua mereka memperlihatkan minat perhatian terhadap agama suku-suku terbelakang dan menggunakan pengetahuan tersebut dalam usaha mereka untuk menyakinkan kita bahwa. Kedua, “... semua yang punya perhatian terhadap kajian agama harus memahami bahwa satu kajian tentang kepercayaan dan praktek agama suku-suku terbelakang, yang ragamnya begitu banyak, dapat menolong kita untuk sampai pada kesimpulankesimpulan tertentu tentang gambaran agama secara umum (generalisasi), dan karena itu juga tentang apa yang disebut sebagai agama tinggi, atau agama positif, atau agama wahyu, termasuk agama kita sendiri.”

Agama-agama suku-suku terbelakang itu memberikan semua data yang berguna bagi satu analisis komparatif yang bertujuan untuk menentukan ciri-ciri utama dari fenomena keagamaan, dan membuat pernyataan-pernyataan significan, umum, dan valid tentang agama-agama tersebut. Untuk memahami hal-ehwal tentang agama wahyu (revealed religion), kita harus memahami hal-ehwal yang disebut agama alamiah (natural religion), karena tidak ada yang dapat diwahyukan tentang sesuatu jika manusia belum punya pemikiran tentang hal ehwal tersebut. Dikotomi antara agama alamiah dan agama wahyu adalah palsu. Namun demikian, untuk dapat memahami gambaran dari agama alamiah dengan metode komparatif bukanlah hal yang mudah. Karena bahasa atau istilah-istilah yang digunakan oleh orang-orang primitif tersebut berkenaan dengan pemikiran dan praktek dalam agama mereka, meskipun dapat diterjemahkan secara harfiah ke dalam bahasa kita, namun makna yang sesungguhnya yang mereka maksudkan mungkin berbeda dari apa yang kita tangkap. 
Fenomena yang seperti inilah yang juga dialami oleh sebagian orang Islam ketika mereka menerjemahkan dan menafsirkan Al Qur'an, dan menerjemahkan Injil oleh orang Kristiani ke dalam bahasa Melayu. Al Qur'an ditulis (diturunkan) dalam bahasa Arab, dalam lingkungan masyarakat Arab Mekah dan Madinah, dan Injil dalam bahasa Ibrani dalam lingkungan masyarakat Israel yang sedang dijajah oleh bangsa Romawi. Bayangkan, apa yang ada dalam pikiran anda ketika membaca beberapa kalimat yang berasal dari laporan-laporan etnografi kuno yang disunting oleh A.E. Crawley dalam bukunya The Mystic Rose (1927), "Daging dari seorang musuh yang kalah dimakan di Timur laut untuk mengobati impotence. Orang Halmahera meminum darah musuh yang kalah agar supaya menjadi berani. Di Amboina, panglima-panglima perang minum darah musuh yang dibunuhnya untuk mendapatkan keberanian. Orang Celebes minum darah musuh untuk membuat mereka kuat." Pertanyaan pertama atas berita-berita ini adalah seberapa jauh laporan-laporan ini mengandung kebenaran. Seandainya terdapat kebenaran, masih diperlukan kerja lain dalam membaca laporan ini, yaitu penafsiran yang benar atas peristiwaperistiwa tersebut.

Bagaimanapun, sesungguhnya seorang sosioantropolog tidak begitu peduli sangat dengan "kebenaran atau kekarutan dari kepercayaan agama... Tidak mungkin seorang peneliti itu akan tahu apakah makhluk adikodrati dalam agama primitif atau agama apa saja benar-benar ada atau tidak. Bagi para sosioantropolog, yang utama dari agama-agama itu adalah sebagai fakta sosial, sociological facts bukan theological facts," kata EvansPritchard. Kepentingan mereka hanyalah dengan hubungan antara satu agama dengan agama yang lain dan dengan faktafakta sosial lain. Ini adalah pandangan daripada Evans-Pritchard dalam kajian agama dari sudut pandang sosiokultural. Dalam mempelajari agama dari segi sosioantropologi pengkaji harus berhatihati. Mereka harus dapat meletakkan diri mereka dengan benar.

Di Indonesia, dimana peneliti agama adalah orang yang beragama, maka mereka menduduki dua posisi yang bertentangan dalam waktu yang bersamaan. Di satu sisi mereka adalah religious man, orang yang beragama, di sisi lain mereka kita adalah saintist yang sedang belajar tentang agama-agama manusia. Memelajari agama dari sudut sosioantropologi dapat bertujuan untuk mendapatkan pengetahuan yang luas tentang berbagai agama manusia di muka bumi, atau melihat agama sendiri dalam konteks keanekaragaman agama tersebut, atau menemukan hakekat sejati dari manusia sebagai makhluk yang mengandung sifat keilahian.

\section{Daftar Pustaka}

al-Abdali, Faruq al-Sheikh Abd al-Syekh Najm (2008). Sains dari Perspektif Kitab Samawi. Kuala Lumpur: Institut Terjemahan Negara Berhad.

Baiquni, A. (1983). Islam dan Ilmu Pengetahuan Modern. Jakarta: Penerbit Pustaka.

Berger, Peter (1969). The Sacred Canopy. Elements of a Sociological Theory of Religion. New York: Anchor Books.

Connolly, Peter (ed.) (2009). Aneka Pendekatan Studi Agama. Yogyakarta: LkiS.

Crowley, A. E. (1927). The Mystic Rose.

Darwin, Charles (1958). Origin of Species

Durkheim, Emile. (1966/1938). The Rules of Sociological Method. New York: The Free Press.

Eller, Jack David (2007). Introducing Anthropology of Religion. Culture to the Ultimate. New York \& London: Routledge.

Evans-Pritchard, E.E. (1965)Theories of Primitive Religion. Oxford University Press.

Fallding, Harold (1974). The Sociology of Religion. An Explanation of the Unity and 
Diversity in Religion. Toronto: McGrawHill Ryerson Limited.

Firth. Raymond (1996). Religion: a Humanist Interpretation. London and New York: Routledge.

Frazer, James G (1955). The Golden Bough. A Study in Magic and Religion. Abridge edition. New York: St. Martins Press.

Geertz, C. (1966) "Religion as a cultural system,” in M. Banton (ed.), Anthropological Approaches to the Study of Religion. London: Tavistock.

Goodenough, Ward H. (1981/1971). Culture, Language, and Socieity. Menlo Park, Calif.: The Benjamin/Cummings Publishing Company, Inc.

Haught, John F. (2004) Perjumpaan Sains dan Agama; Dari Konflik ke Dialog, terjemahan. Bandung: Mizan.

Haviland, B. William A (1996). Cultural Anthropology ( $8^{\text {th }}$ ed.). Harcourt Brace College Publishers.

Hj. Othman, Mohd Yusoff \& AbdulSalam Yussof (2009). Sains, Mayarakat dan Agama. Kuala Lumpur: Utusan Publications.

Kartanegara, Mulyadi (2005). Integrasi Ilmu. Sebuah Rekonstruksi Holistik. UIN Jakarta Press.

Lessa, A. William \& Z. Evon Vogt (ed.). Reader in Comparative Religion: An Anthropological Approach. Harper and Row Publications, 1978.

Lewis, Ioan M. (2003). Social \& Cultural Anthropolpogy in Perspective ( $3^{\text {rd }}$ ed.). New Brunswick (USA): Transaction Publishers.

Luckmann, Thomas (1972). The Invisible Religion. New York: The Macmillan Company.

McGuire, Meredith B. (2002). Religion: the social context $\left(5^{\text {th }}\right.$ ed.). Wadsworth.

Morris, Brian (1987). Anthropological Studies of Religion. An introductory text. Cambridge: Cambridge University Press.

Muller, K.M.F. Max (1892). Anthropological Religion. London: Longmans, Green, and Co.

O’Dea, Thomas F (1969). The Sociology of Religion. New Delhi: Prentice-Hall of India Private Limited.

Pals, Daniel L. (2011). Seven Theories of Religion (terjemahan). Jogjakarta: IRCiSoD.
Pelto, Pertti J.; and Gretel H. Pelto (1978). Anthropological Research (2 ${ }^{\text {nd }}$ ed.). New York: Cambridge University Press.

Pye, Michael (1972). Comparative Religion. An Introduction Through Source Materials. Newton Abbot: David \& Charles.

Radin, Paul (1957). Primitive Religion: Its Nature and Origin. New York: Dover Publications.

Ranganathananda, Swami (1964). Swami Vivekananda's Synthesis of Science and Religion. Calcutta: The Ramakrisna Mission Institute of Calcutta.

Robertson, Roland (ed.) (1988). Agama: dalam analisis dan interpretasi sosiologis. Jakarta: CV Radjawali.

Rudyansjah, Tony (ed.) (2012). Antropologi Agama. Wacana-Wacana Mutakhir dalam Kajian Religi dan Budaya. Jakarta: Penerbit Universitas Indonesia.

Russell, C.A (ed.) (1979). Science and Religiious Belief. A Selected of Recent Historical Studies. The Open University Press.

Saifudin, Achmad Fedyani (2000). Agama Dalam Politik Keseragaman. Jakarta: Badan Penelitian dan Pengembangan Agama, Departemen Agama RI.

Schrarf, Betty (1995/1970). Kajian Sosiologi Agama. Yogya: PT. Tiara Wacana.

Smart, Ninian (1971). The Religious Experince of Mankind. New York: Charles Scribner's Sons.

Smith, Huston (2008/1958). Agama-Agama Manusia (terjemahan). Jakarta: Yayasan Obor Indonesia.

Spiro, Melford (1966) "Religion: Problems of definitions and explanation," in M. Banton (ed.), Anthropological Approaches to the Study of Religion. London: Tavistock.

Spradley, James P. \& David W. McCurdy (2003). Conformity and Conflict: Readings in Cultural Anthropology ( $11^{\text {th }}$ ed.), Harper Collins Publishers. [GN325 Con]

Tylor, E. B. (1958). Religion in Primitive Culture. Part II of "Primitive Culture." New York: Harper Torchbooks.

Tremmel, William Colleley (1976). Religion. What is It? New York: Holt Rinehart and Winston.

Vernon, Glenn M. (1962). Sociology of Religion. McGraw-Hill.

Ranganathananda, Swami (1964). Swami Vivekananda's Synthesis of Science and 
Religion. Calcutta: The Ramakrisna Mission Institute of Calcutta.

Wach, Joachim (1977/1944). Sociology of Religion. Chicago: The University of Chicago Press.

Wallace, F.C (1966). Religion: An anthropological view. New York: Random House.

Yinger, Milton (1957). Religion, Society, and the Individual: An Introduction to the Sociology of Religion. New York: Macmillan. 